\title{
Effects of canopy opening on height and diameter growth in naturally regenerated beech seedlings
}

\author{
Catherine Collet ${ }^{\mathrm{a}, *}$, Olivier Lanter ${ }^{\mathrm{a}}$ and Marta Pardos ${ }^{\mathrm{b}}$ \\ ${ }^{a}$ Équipe Croissance et Production, INRA Nancy, 54280 Champenoux, France \\ ${ }^{\mathrm{b}}$ Departamento de Selvicultura, CIFOR-INIA, Ap. Correos 8.111, 28080 Madrid, Spain
}

(Received 4 February 2000; accepted 13 November 2000)

\begin{abstract}
In order to analyze the growth dynamics of beech seedlings growing under contrasting canopy conditions, a beech stand in which two types of canopy opening (canopy release or gap creation) had been applied in 1995 was selected. Three and four years after the canopy had been opened, 113 naturally regenerated seedlings were sampled in gaps or under the canopy. The effects of canopy opening and seedling age on annual height and diameter growth were analyzed using mixed models. Under closed canopy, average annual seedling height and diameter increments were $1.2 \mathrm{~cm}$ and $0.18 \mathrm{~mm}$, respectively. Diameter growth increased in the first year after the canopy had been opened, and exhibited considerable inter-annual variation related to climatic conditions. Conversely, height growth did not increase immediately after canopy opening, but increased regularly in the following years. Four years after the gap had been created, annual seedling height and diameter growth were $9.5 \mathrm{~cm}$ and $0.49 \mathrm{~mm}$ respectively in the gaps, and $3.8 \mathrm{~cm}$ and $0.21 \mathrm{~mm}$ respectively under released canopy. Age did not affect the dynamics of seedling growth.
\end{abstract}

gap / shade tolerance / natural regeneration / Fagus sylvatica L. / mixed model

Résumé - Effets de l'ouverture du couvert sur la croissance en hauteur et en diamètre de semis naturels de hêtre. La dynamique de croissance de jeunes semis de hêtre poussant dans les conditions de couvert contrastées a été étudiée dans un peuplement à base de hêtre dans lequel deux types d'ouverture du peuplement ont été réalisés. En 1995, un simple relevé de couvert a été effectué dans l'ensemble du peuplement et des trouées ont été ouvertes dans certaines parties. En 1998 et 1999, 113 semis naturels de hêtre ont été récoltés sous couvert ou dans les trouées. Les effets combinés de l'ouverture du couvert et de l'âge des semis sur la croissance en hauteur et en diamètre des semis ont été analysés à l'aide de modèles linéaires mixtes. Les semis sous couvert présentaient un accroissement annuel en hauteur de $1,2 \mathrm{~cm}$ et un accroissement annuel en diamètre de $0,18 \mathrm{~mm}$. La croissance en diamètre a augmenté dès la premère année après l'ouverture du couvert et a ensuite montré de fortes variations inter-annuelles liées à des variatons climatiques. En revanche, l'augmentation de la croissance en hauteur à la suite de l'ouverture du peuplement n'a pas été immédiate, et a continué de manière progressive dans les quatre années suivantes. Quatre ans après l'ouverture du peuplement, les accroissements annuels en hauteur en en diamètre étaient de $9,5 \mathrm{~cm}$ and $0,49 \mathrm{~mm}$ respectivement pour les semis dans les trouées et de $3,8 \mathrm{~cm}$ and $0,21 \mathrm{~mm}$ respectivement pour les semis sous relevé de couvert. La croissance des semis n'est pas apparue liée à l'âge.

trouée / tolérance à l'ombrage / régénération naturelle / Fagus sylvatica L. / modèle mixte

\section{INTRODUCTION}

In France, most beech (Fagus sylvatica L.) stands are naturally regenerated using the shelterwood method.
This method involves two main steps: canopy release consisting in removing of the understory and some dominated overstory trees, and progressive removal of the overstory trees. The purpose of canopy release is to

* Correspondence and reprints

Tel. (33) 03833940 43; Fax. (33) 03833940 34; e-mail: collet@nancy.inra.fr 
increase the amount of light reaching the forest floor and therefore enhance seedling establishment. It is generally performed uniformly in the whole stand and does not induce any particularly high spatial variability. The purpose of progressive overstory removal is to suppress trees of poor quality and favor the growth of the seedlings having appeared after canopy removal. Trees are felled in places where poor-quality trees are present or in places where a sufficient number of well-developed seedlings have grown. The size and spatial distribution of the gaps created in the canopy depend on the characteristics of the mature stand and the growing regeneration. Removing overstory induces high spatial variability within the stand.

Both canopy release and gap opening induce sudden changes in seedling growth conditions. Before canopy release, the relative light intensity in mature beech stand is usually below $3 \%[9,26]$. It usually raises to between 5 and $15 \%$ after canopy release and up to much higher values after gap creation, depending on gap size. Besides solar radiation, all other microclimatic variables (air and soil temperature, rainfall, air humidity and wind) are immediately modified by canopy release and gap creation [2].

High spatial and temporal variability in canopy closure are the main characteristics of stands undergoing regeneration. A prerequisite to understanding the establishment and growth of seedlings in natural regeneration is to study the response of seedlings to both types of variation. The effects of the degree of canopy closure on beech seedlings have been studied under natural and controlled conditions. Early studies have shown that beech seedlings are able to persist for a long time under deep shade with reduced growth, and that seedling growth increases progressively with the degree of canopy opening [26]. More recent studies have shown that the morphology of beech seedlings is altered by the degree of canopy closure, as a result of a changing biomass allocation pattern with the amount of light received $[7,8,10,14,25]$. Far fewer studies have analyzed the effects of sudden exposure to light on beech seedlings. Experiments under controlled conditions [24, 27, 28] showed that beech seedlings have large acclimation potential determined by physiological and morphological plasticity. This acclimation potential should enable them to adapt rapidly to the new light environment created by canopy opening.

The objective of the present study is to analyze the growth of naturally regenerated beech seedlings in relation to canopy opening. We first examine growth in height and diameter of beech seedlings grown under closed canopy, and then examine seedling response to canopy release and gap creation.

\section{MATERIALS AND METHODS}

\subsection{Study site}

The research site was located in a beech stand $\left(48^{\circ} 38^{\prime} \mathrm{N}, 06^{\circ} 07^{\prime} \mathrm{E}\right.$, alt. $\left.380 \mathrm{~m}\right)$ in the state-owned forest of Haye, located on a limestone plateau near Nancy, France. Soil conditions varied within the study area, and ranged from rendosol to calcisol types (defined according to Baize and Girard [4]). The rendosol type consists of a dark-brown carbonated A horizon $(15$ to $20 \mathrm{~cm}$ thick) with 40 to $60 \%$ of stones, on a fragmented $\mathrm{C}$ horizon. The calcisol type consists of a dark-brown carbonate-free A horizon (15 to $20 \mathrm{~cm}$ thick) with 30 to $50 \%$ of stones, on a reddish carbonate-free $\mathrm{S}$ horizon (15 to 25 $\mathrm{cm}$ thick), on a fragmented $\mathrm{C}$ horizon. Maximum extractable water (MEW) was evaluated for each soil, using the calculation procedure and typical values for Haye Forest soils given by Bigorre et al. [5]. Maximum extractable soil water ranged between $58 \mathrm{~mm}$ for the rendosol type and $68 \mathrm{~mm}$ for the calcisol type.

The canopy was dominated by beech, with numerous sub-dominating hornbeam (Carpinus betulus L.). The stand was a mature stand entering the regeneration phase. The first silvicultural operations to regenerate the stand had already been carried out by the Forest Service when the study begun. In spring 1995, a slight canopy release was performed in order to enhance beech fructification and seed germination. In places where beech regeneration already existed, the trees were felled and 10 - to 20 -m-wide gaps were created. The study was performed in spring 1998 and 1999, 3 and 4 years after the stand had been opened.

In spring 1998, a total number of 66 seedlings were sampled in two plots located in gaps and in two plots located under canopy. In spring 1999, a total number of 47 seedlings were sampled in a plot located in a gap and in two plots located under canopy. Only seedlings that had germinated before 1995 were chosen. Each plot was within a 5-m diameter circle, and all plots were located within a $100 \mathrm{~m} \times 100 \mathrm{~m}$ area. Soil and light conditions were described for each plot (table I). Relative light intensity reaching the forest floor was estimated using hemispherical photograph analysis. In July 1999, one hemispherical photograph was taken at the center of each plot at $1.2 \mathrm{~m}$ above ground, and the percent of total radiation (direct and diffuse) penetrating through the canopy was calculated by using hemIMAGE software [6]. It is important to note that only the light conditions prevailing in 1999 were evaluated, and that we have no information about the conditions prevailing before canopy release in 1995. The number of sampled seedlings, the average seedling height and seedling basal diameter, and the 
maximum and minimum seedling ages for each plot are given in table $I$.

\subsection{Annual water stress indices}

Water deficit indices were calculated each year between 1984 and 1998 using a daily water balance model developed by Granier et al. [11]. The input data required by the model are:

- Climatic data: daily potential evapotranspiration and daily rainfall. These data were collected at the INRA weather station at Amance, $20 \mathrm{~km}$ east of the study site.

- A site parameter: maximum extractable soil water (MEW). An average value of $62 \mathrm{~mm}$ was chosen for the whole study site.

- A stand parameter: leaf area index (LAI). An estimated value of 4.5 was chosen for the 1984-1998 period, from values measured in similar beech stands [11].

The model computes daily variations in relative extractable soil water (REW), which is the amount of extractable water in the soil relative to the maximum extractable water. From these values, the model computes two seasonal indices: (1) a water stress index which, over the growing season, cumulates the difference between REW and the critical value of REW $\left(\mathrm{REW}_{\mathrm{C}}\right.$, value below which water deficit occurs and tree transpiration decreases) and (2) the date when water deficit begins. Water deficit is assumed to occur when REW drops below $40 \%$ of MEW [11]. The model indicates that, during the 1984-1998 period, the annual water-stress index ranged between 20 and 73, and the onset of water deficit ranged between May 23 and August 21.

\subsection{Measurements}

In all 113 seedlings, the annual growth units (GUs) on the dominant shoot were identified by examining the scars left by the winter buds, and the length of each GU $(\mathrm{cm})$ was measured. Since all seedlings presented high apical dominance, the dominant shoot could always be determined without ambiguity.

In 18 seedlings (11 seedlings collected under closed canopy and 7 collected in gaps), cross-sections were cut out at the seedling base for ring analysis. Three- to tenmillimeter-long samples were cut at the base of the hypocotyl. These samples were embedded into carbowax: they were immersed in a series of polyethylene glycol 1500 solutions (progressively 30, 50 100\%) under vacuum and left in each solution for $24 \mathrm{~h}$. Fifteenmicrometer-thick microsections were cut out from the impregnated pieces with a sliding microtome. The microsections were rinsed in water, stained with an aqueous $1 \%$ solution of safranin for one minute, and rinsed in $96 \%$ alcohol. The microsections were then placed on slides and mounted in Canada balsam for microscopic examination. The width $(\mathrm{mm})$ of the pith and of each annual ring was measured for two opposite radii with a micrometer (precision: 1/100 $\mathrm{mm}$ ).

\subsection{Statistical analysis}

In order to analyze the effects of canopy opening and seedling age on seedling growth, the seedlings were separated into two canopy closure levels according to their sampling location (level 1: in gaps, level 2: under canopy), and into 3 age cohorts according to the year they germinated (cohort 1: 1983-1986, 36 seedlings; cohort 2: 1987-1990, 40 seedlings; cohort 3: 1991-1994, 37 seedlings). The seedlings were grouped into age

Table I. Characteristics of the seven sampling locations: canopy (closed or gap), soil (calcisol or rendosol), relative light intensity (percentage of total radiation penetrating through the canopy), number of seedlings sampled at each location, and characteristics of the seedlings: total height (mean \pm SEM), basal diameter (mean \pm SEM), and age (minimum-maximum).

\begin{tabular}{lllccrr}
\hline Sample & Canopy & Soil & $\begin{array}{c}\text { Relative light } \\
\text { intensity }(\%)\end{array}$ & $\begin{array}{c}\text { Number of } \\
\text { seedlings }\end{array}$ & H (cm) & D (mm) \\
\hline 1 & gap & calc & 52.3 & 8 & $37.9 \pm 10.4$ & $7.58 \pm 0.63$ \\
2 & gap & calc & 32.7 & 23 & $25.5 \pm 7.5$ & $4.78 \pm 0.26$ \\
3 & closed & rend & 5.4 & 17 & $17.0 \pm 6.7$ & $2.95 \pm 0.11$ \\
4 & closed & rend & 10.7 & 18 & $20.2 \pm 4.6$ & $3.23 \pm 0.14$ \\
5 & gap & rend & 26.5 & 18 & $33.3 \pm 7.6$ & $4.83 \pm 0.22$ \\
6 & closed & rend & 15.5 & 21 & $23.5 \pm 8.8$ & $3.55 \pm 0.22$ \\
7 & closed & rend & 5.01 & 8 & $26.1 \pm 9.4$ & $5-14$ \\
\hline
\end{tabular}


cohorts in order to obtain a sufficient number of observations at each age factor level so as to make it possible to calculate the mean for each level and make comparisons among levels. Three other effects that might have affected seedling growth were also analyzed (seedling, sampling location, and year effects). A series of mixed-effect models (containing random and fixed effects) were used to analyze seedling growth. Annual height and diameter growth were fitted as follows:

$$
\begin{aligned}
Y_{n y c l p(l)}= & \theta+\alpha_{y}+\beta_{c}+\chi_{l}+\delta_{p / l}+(\alpha \beta)_{y c}+(\alpha \chi)_{y l} \\
& +(\beta \chi)_{c l}+\gamma_{n}+\varepsilon_{n y c l p(l)}
\end{aligned}
$$

where $n$ denotes the seedling number, $y$ the year, $c$ the cohort number, $l$ the canopy closure level and $p(l)$ the sampling location in a canopy closure level. $Y_{n y c l p(l)}$ is the measured height or diameter increment, $\theta$ the overall mean annual height increment or annual diameter increment, $\alpha_{y}, \beta_{c}, \chi$, and $\delta_{p(l)}$ the "year", "cohort", "canopy closure" and "sampling location in canopy closure level" effects (fixed effects) respectively, $\gamma_{n}$ the "seedling" effect (random effect), $(\alpha \beta)_{y c},(\alpha \chi)_{y l}$ and $(\beta \chi)_{c l}$ the interaction effects, and $\varepsilon_{\text {nyclp }(l)}$ the random error.

Separate models for height and diameter were established. We analyzed seedling growth before and after 1995 (year of canopy opening) separately. After 1995, the seedlings sampled in gaps and under canopy experienced two different canopy closure intensities. Conversely, before 1995, seedlings sampled in the two canopy closure levels were assumed to grow under similar conditions, and the effect of the "canopy closure" factor was tested in order to check if the seedlings sampled in gaps or under canopy had similar growth before canopy opening.
For each of the four analyses (height and diameter increment, before and after 1995), a complete model that followed equation (1) was established to test the effects of all the factors (table II). These models did not make it possible to calculate or compare mean values for each factor level, because of an insufficient number of observations, but they did make it possible to determine which factors were significant for each analysis. A reduced model that contained only the statistically significant factors was then constructed for each analysis. The reduced model made it possible to calculate the adjusted mean (least-squares means) for each factor level and compare certain factor levels. All analyses were performed using the MIXED procedure from the SAS system [13].

\section{RESULTS}

The reduced model constructed for height growth before canopy opening included the year, canopy closure level, year $\mathrm{x}$ canopy closure level, and seedling effects $\left(\alpha_{y}, \chi_{l},(\alpha \chi)_{y l}\right.$ and $\left.\gamma_{n}\right)$. In model 1 , all the effects were statistically significant except for the year effect (table III). Least-squares means were then calculated for each canopy closure level $\times$ year combination (figure 1 ). Annual height increment showed no statistically significant inter-annual variation (table III), although the water stress index varied between 20 and 73 (figure 1).

The reduced model constructed for height growth after canopy opening included the year, canopy closure level, sampling location, seedling and year $\times$ canopy closure level effects $\left(\alpha_{y}, \chi_{l}, \delta_{p(l)}, \gamma_{n},(\alpha \chi)_{y l}\right)$. In model 2, all the included effects were significant. On average over the 1994-1995 period, the seedlings sampled in gaps

Table II. Statistical significance of the effects tested in four complete models that follow equation (1) used to model seedling height or diameter increment between 1983 and 1994 or between 1994 and 1998. The total number of observations and the number of

\begin{tabular}{|c|c|c|c|c|c|}
\hline \multirow{2}{*}{\multicolumn{2}{|c|}{$\begin{array}{l}\text { Dependent variable } \\
\text { Period }\end{array}$}} & \multicolumn{2}{|c|}{ Height increment } & \multicolumn{2}{|c|}{ Diameter increment } \\
\hline & & $1983-1994$ & 1994-1998 & 1983-1994 & 1994-1998 \\
\hline \multirow{2}{*}{\multicolumn{2}{|c|}{$\begin{array}{l}\text { Number of seedlings } \\
\text { Number of observations }\end{array}$}} & 113 & 113 & 18 & 18 \\
\hline & & 568 & 532 & 81 & 79 \\
\hline Random effect: & seedlings & 0.0001 & 0.012 & 0.14 & 0.19 \\
\hline Fixed effects: & year & 0.99 & 0.0001 & 0.052 & 0.0001 \\
\hline & cohort & 0.012 & 0.22 & 0.086 & 0.38 \\
\hline & canopy closure level & 0.024 & 0.0001 & 0.21 & 0.10 \\
\hline & sampling location & 0.090 & 0.0001 & 0.27 & 0.23 \\
\hline & year $\times$ cohort & 0.042 & 0.13 & 0.0003 & 0.79 \\
\hline & year $\times$ canopy closure level & 0.019 & 0.0001 & 0.022 & 0.048 \\
\hline & cohort $\times$ canopy closure level & 0.009 & 0.62 & 0.44 & 0.29 \\
\hline
\end{tabular}
seedlings used are indicated for each model. 
Table III. Statistical significance of the effects tested in four reduced models used to model seedling height or diameter increment between 1983 and 1994 or between 1994 and 1998. The total number of observations and the number of seedlings used are indicated for each model. Models are numbered as in the text.

\begin{tabular}{|c|c|c|c|c|}
\hline \multirow{3}{*}{$\begin{array}{l}\text { Dependent variable } \\
\text { Period } \\
\text { Model number }\end{array}$} & \multicolumn{2}{|c|}{ Height increment } & \multicolumn{2}{|c|}{ Diameter increment } \\
\hline & $1983-1994$ & 1994-1998 & 1983-1994 & 1994-1998 \\
\hline & model 1 & model 2 & model 3 & model 4 \\
\hline Number of seedlings & 113 & 113 & 18 & 18 \\
\hline Number of observations & 568 & 532 & 81 & 79 \\
\hline Random effect: seedlings & 0.0001 & 0.0013 & 0.057 & 0.086 \\
\hline Fixed effects: $\quad$ year & 0.056 & 0.0001 & 0.37 & 0.0001 \\
\hline canopy closure level & 0.010 & 0.0001 & 0.34 & 0.0002 \\
\hline sampling location & / & 0.0001 & 1 & l \\
\hline year $\times$ canopy closure level & 0.0029 & 0.0001 & 0.019 & 0.0014 \\
\hline
\end{tabular}

grew more rapidly than the seedlings sampled under canopy, and the difference was highly significant for each year, even in 1994 before canopy opening (figure 1). In the first year after the canopy was opened, height increment remained constant compared to growth before canopy opening. From 1995 to 1998, height increment increased every year for both the seedlings sampled in gaps and those sampled under canopy. The smaller increase in height growth in 1997 may be related to the previous year's drought. Large differences in annual seedling height increment existed among sampling locations at the same light level, and these differences may be partly explained by the relative light intensity (figure 2).

Reduced models (models 3 and 4), including the year, canopy closure level, year x canopy closure level, and seedling effects $\left(\alpha_{y}, \chi_{l},(\alpha \chi)_{y l}\right.$ and $\left.\gamma_{n}\right)$ were used to fit diameter growth (table III). For the 1983-1994 period, only the interaction between year and light level was significant. For the 1994-1998 period, all effects were significant. As for height growth, seedlings sampled in gaps grew more in diameter than seedlings sampled under canopy, and the differences were statistically significant every year, except for 1994 (figure 1). Contrary to height growth, diameter growth increased immediately after the gap had been created, but did not continue to increase in the following years. Annual diameter increments for seedlings sampled under canopy exhibited similar interannual variation to seedlings sampled in gaps, although absolute values were much smaller. Inter-annual variation in diameter increment over the 1995-1998 period may clearly be related to variation in the water stress index: the smallest increments were measured in 1996 and 1998 when the water stress indices were the highest.

\section{DISCUSSION}

\subsection{Seedling survival and growth under canopy}

The wide range of seedling ages observed in natural beech regeneration [22] is related to the capacity of young beech seedlings to survive under low light conditions and to reduced seedling growth under such conditions. Both phenomena are necessary in order to have old and young seedlings present in a regeneration patch: (1) the ability to survive enables old seedlings to continue being present, and (2) the slow growth of the old seedlings enables young seedlings to establish and grow without facing competition from older seedlings.

Experiments under controlled conditions show that the minimum light intensity required for young beech seedlings to survive is around $1 \%$ of total radiation [8, 26]. However, as pointed out by Watt [26], seedlings are never found under such deep shade under natural conditions because of other limiting factors such as water or nutrient availability $[14,20]$. Studies on naturally regenerated stands show that beech seedlings can survive at approximately 3 to $5 \%$ of incident radiation $[9,15,18$, $23,26]$. In the present study, we measured relative light intensity values at the forest floor of between 5 and $15 \%$ after the canopy had been released in 1995 . Prior to canopy release, relative light intensity was probably lower (as suggested by the lower seedling growth rates before 1995), and therefore most likely close to the threshold value given for beech seedling survival.

All the above-cited authors reported greatly reduced seedling growth under low light conditions. We measured an average annual seedling height and diameter increment of $1.2 \mathrm{~cm}$ and $0.17 \mathrm{~mm}$, respectively, and an average number of three leaves on the main axis (data not shown). These are probably threshold values for 


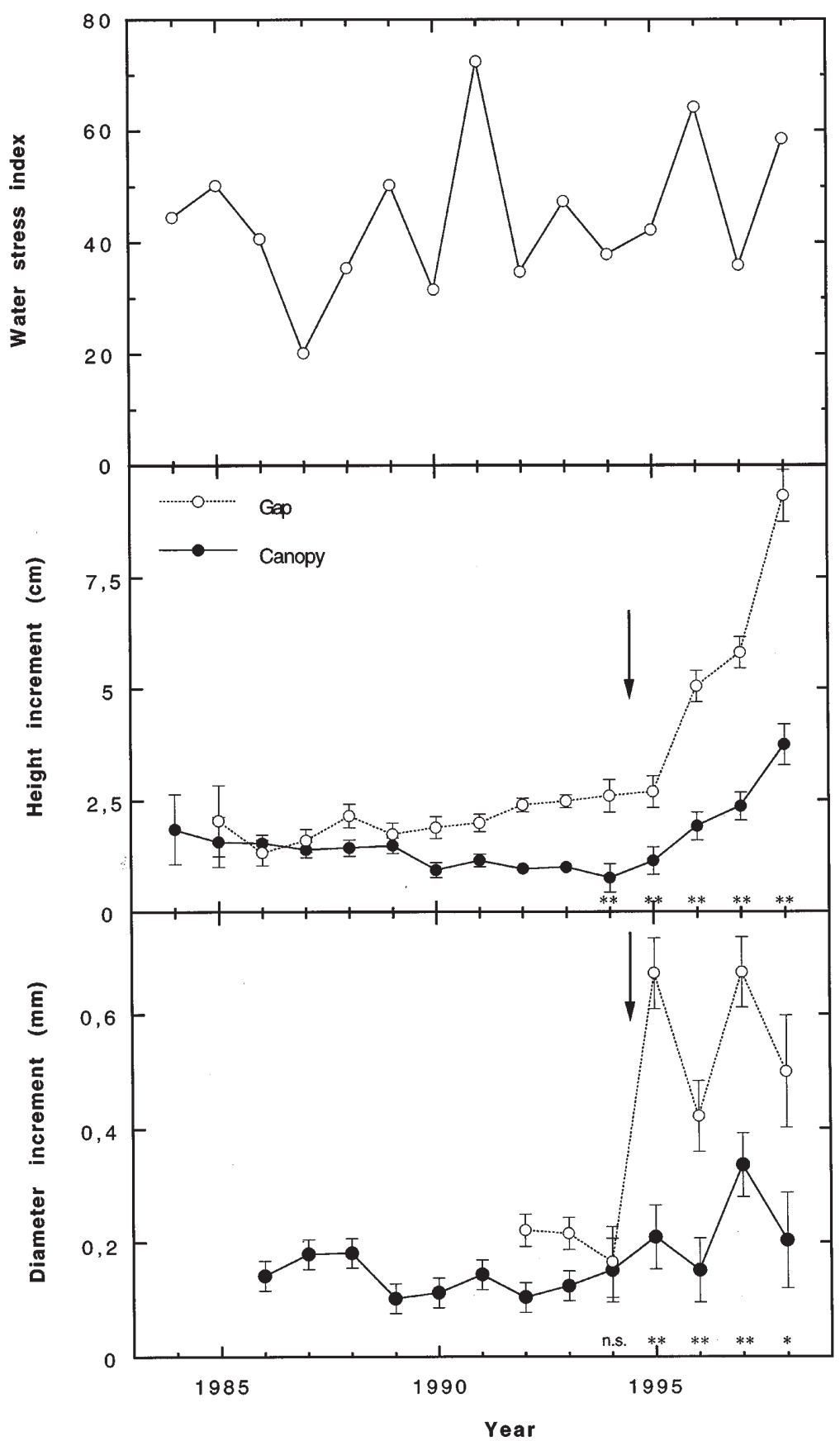

Figure 1. Water stress index, annual height and diameter increments for seedlings sampled under canopy or in gaps (least-squares mean \pm SEM). The arrow indicates the year in which the canopy was released (seedlings sampled under canopy) or the gaps created (seedlings sampled in gaps). The values for height before and after 1994 were calculated using models 1 and 2, and for diameter using models 3 and 4, respectively. The difference in annual height or diameter increment between the seedlings sampled under canopy and the seedlings sampled in gaps was tested for each year between 1994 and 1998: n.s. indicates non significant F-ratio at the $p<0.05$ level of probability, $*$ and $* *$ indicate significant F-ratio at the $p<0.05$ and $p<0.01$ levels of probability respectively. The water stress index was calculated using a daily water balance model [11]. 


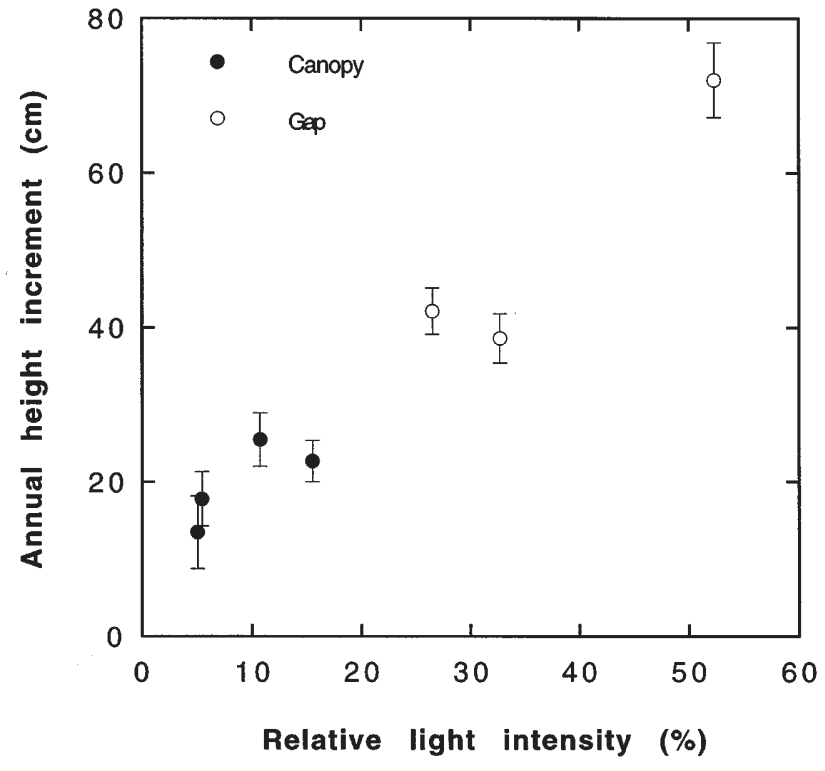

Figure 2. Relationship between average seedling annual height increment (least-square mean \pm SEM) calculated between 1995 and 1998 using model 2 and relative light intensity measured in 1998, in seven sampling locations located in gaps or under canopy.

seedling growth that are necessary for seedling survival. The growth rate of such seedlings is close to the growth rate observed on branches of senescent beech trees or on deep-shaded branches of adult beech trees $[17,19]$.

\subsection{Effects of canopy opening}

One objective of the present study was to analyze seedling response to canopy release and gap creation. Instead of performing an experiment, we decided to sample seedlings in a recently opened stand that exhibited various levels of canopy closure. This choice brought about the main limitation of the study, which was that we did not control the initial conditions before canopy opening. We had no information on initial light conditions in the stand. Moreover, the seedlings sampled in gaps appeared to be initially higher than the seedlings sampled under canopy (although basal diameter was not statistically different). This bias was due to the fact that canopy opening was carried out by the Forest Service which created gaps in places where seedlings were abundant and left canopy in places where seedlings were absent or too small.
Recent studies under controlled conditions, in which the physiological and morphological response of shadeadapted beech seedlings exposed to higher light levels was analyzed, suggest that beech seedlings are able to benefit rapidly from canopy opening [24, 27, 28]. Under natural conditions, we observed that seedling growth increased immediately after gap creation. We evaluated seedling growth by estimating annual height and diameter increments, and we observed that the two variables responded differently to gap formation. Diameter growth increased the first year after the gaps had been opened and showed no clear increasing trend in the following three years. Conversely, height growth did not increase immediately after canopy opening and increased regularly in the following three years. Similar responses of young seedlings to canopy opening have been demonstrated by Aussenac [1,2] for several coniferous species. In agreement with previous results [3,21], we observed that growth was positively associated with the amount of water available during the growing season for diameter growth, and during the previous growing season for height growth. The water balance model indicates that the onset of soil water deficit never occurred before the end of May during the 1995-1998 period. In the Northeast of France, shoot elongation in monocyclic beech seedlings usually takes place at the beginning of May and the development of water deficit after this period has no effect on the current year's height growth. Conversely, diameter growth may continue much later in the growing season and is therefore more dependent on the amount of water available during the current year. Four years after the gap had been created, the seedlings exhibited an average annual height and diameter increment of $9.3 \mathrm{~cm}$ and $0.49 \mathrm{~mm}$, respectively.

Canopy release induced a significant increase in height growth but not in diameter growth. This is most likely related to the fact that, at low light levels and for shade-tolerant species, height growth is usually maintained at lower light levels than diameter growth [12, $16]$. When the canopy was released, the seedlings probably experienced a change in light conditions around the threshold value at which height growth may still vary but diameter growth has already reached a minimum value.

The capacity of the seedlings to benefit from canopy opening seems to be independent of seedling age: the seedlings from the older cohorts (between 9 and 12 years) were able to respond as rapidly as the seedlings from the younger cohorts (between 1 and 4 years). The capacity of beech seedlings to survive deep shade for a long period of time and then respond rapidly to canopy opening has long been known to exist in forestry [26]. The remaining question is how long are the seedlings able to persist beneath a closed canopy and wait for 
growing conditions to improve? We showed that 12year-old seedlings were still able to regain active growth after canopy opening, and it would now be interesting to study the capacity of older seedlings to do the same.

Acknowledgements: We thank Jean-Claude Pierrat (ENGREF, Nancy) for his assistance with the stastistical analyses, and André Granier for running water balance model simulations.

\section{REFERENCES}

[1] Aussenac G., À propos de la crise de découvert des résineux. Analyse d'un cas en Lorraine, Rev. For. Fr. 29 (1977) 127-130.

[2] Aussenac G., Interaction between forest stands and microclimate: ecophysiological aspects and consequences for silviculture, Ann. For. Sci. 57 (2000) 287-301.

[3] Badeau V., Étude dendroécologique du hêtre (Fagus sylvatica $\mathrm{L}$.) sur les plateaux calcaires de Lorraine, Ph.D. Thesis, Université Nancy I, 1995.

[4] Baize D., Girard M.C., A sound reference base for soils. The "référentiel pédologique" (in English), INRA, Paris, 1998.

[5] Bigorre F., Tessier D., Gras F., Granier A., Étude des propiétés hydriques des sols et de leur rôle dans le bilan hydrique. Application à des sols situés sur le Dogger Lorrain en forêt de Haye, Rapport Interne Agence de l'eau RhinMeuse/CNRS, 1996.

[6] Brunner A., A light model for spatially explicit forest stand models, For. Ecol. Manage. 107 (1998) 19-46.

[7] Burschel P., Huss J., Die Reaktion von Buchensämlingen auf Beschattung, Forstarchiv 35 (1964) 225-233.

[8] Burschel P., Schmaltz J., Die Bedeutung des Lichtes für die Entwicklung junger Buchen, Allg. Forst Jagd Z. 136 (1965) 193-210.

[9] Emborg J., Understorey light conditions and regeneration with respect to the structural dynamics of a near-natural deciduous forest in Denmark, For. Ecol. Manage. 106 (1998) 83-95.

[10] Gansert D., Sprick W., Storage and mobilization of non-structural carbohydrates and biomass development of beech seedlings (Fagus sylvatica L.) under different light regimes, Trees 12 (1998) 247-257.

[11] Granier A., Bréda N., Biron P., Villette S., A lumped water balance model to evaluate duration and intensity of drought constraints in forest stands, Ecol. Model. 116 (1999) 269-283.

[12] Hara T., Kimura M., Kikuzawa K., Growth patterns of tree height and stem diameter in populations of Abies veitchii, A. mariesii and Betula ermanii, J. Ecol. 79 (1991) 1085-1098.

[13] Littel R.C., Milliken G.A., Stroup W.W., Wolfinger R.D., SAS system for mixed models, SAS Institute Inc., Cary, North Carolina, 1996.
[14] Madsen P., Growth and survival of Fagus sylvatica seedlings in relation to light intensity and soil water content, Scand. J. For. Res. 9 (1994) 316-322.

[15] Madsen P., Larsen J.B., Natural regeneation of beech (Fagus sylvatica L.) with respect to canopy density, soil moisture and soil carbon content, For. Ecol. Manage. 97 (1997) 95-105.

[16] Morgan D.C., Smith H., Asymmetric relationship between phytochrome-induced development and species habitat, for plants grown in simulated natural radiation, Planta 145 (1979) 253-258.

[17] Nicolini E., Approche morphologique du développement du hêtre (Fagus sylvatica L.), Ph.D. Thesis, Université Montpellier II, 1997.

[18] Oswald H., Conditions de germination des faînes, de survie et de croissance des semis. Influence des facteurs climatiques et de la lumière, in: Tessier du Cros E. (Ed.), Le Hêtre, Institut National de la Recherche Agronomique, Paris, 1981, pp. 221-224.

[19] Percebois E., Activité cambiale dans les axes à faibles croissance chez le hêtre, le châtaignier et le pin laricio, et dans les rameaux courts de merisier, MS Thesis, Université de Nancy II, 1997.

[20] Ponge J.F., Ferdy J.B., Growth of Fagus sylvatica saplings in an old-growth forest as affected by soil and light conditions, J. Veg. Sci. 8 (1997) 789-796.

[21] Power S.A., Temporal trends in twig growth of Fagus sylvatica $\mathrm{L}$. and their relationships with environmental factors, Forestry 67(1994) 13-30.

[22] Schütz J.P., Sylviculture 1, Principes d'éducation des forêts, Presses Polytechniques et Universitaires Romandes, Lausanne, 1990.

[23] Suner A., Röhrig E., Die Entwicklung des Buchennaturverjüngung in Abhängigkeit von des Auflichtung des Altbestandes, Forstarchiv 51 (1980) 145-149.

[24] Tognetti R., Johnson J.D., Michelozzi M., Ecophysiological responses of Fagus sylvatica seedlings to changing light conditions. I. Interactions between photosynthetic acclimation and photoinhibition during simulated canopy gap formation, Physiologia Plantarum 101 (1997) 115-123.

[25] Van Hees A.F.M., Growth and morphology of pedunculated oak (Quercus robur L.) and beech (Fagus sylvatica L.) seedlings in relation to shading and drought, Ann. Sci. For. 54 (1997) 9-18.

[26] Watt A.S., On the ecology of british beechwoods with special reference to their regeneration, Ecology 11 (1923) $1-48$.

[27] Welander T., Ottosson B., Influence of photosynthetic photon flux density on growth and transpiration in seedlings of Fagus sylvatica, Tree Physiol. 17 (1997) 133-140.

[28] Welander T., Ottosson B., The influence of shading on growth and morphology in seedlings of Quercus robur L. and Fagus sylvatica L., For. Ecol. Manage. 107 (1998) 117-126. 